\title{
A new species of Bothriembryon (Mollusca: Gastropoda: Bulimulidae) from the Pliocene Roe Calcarenite, Eucla Basin, Western Australia
}

\author{
George W. Kendrick \\ Department of Earth and Planetary Sciences, \\ Western Australian Museum, Francis Street, Perth, Western Australia 6000, Australia \\ and \\ School of Earth and Geographical Sciences, \\ The University of Western Australia, Crawley, Western Australia 6009, Australia
}

\begin{abstract}
Bothriembryon kremnobates sp. nov., a terrestrial snail, is described from the marine Roe Calcarenite of the southern Eucla Basin. This constitutes a first Pliocene record for the genus, hitherto known only from the Miocene? and Quaternary.
\end{abstract}

\section{INTRODUCTION}

The Roe Calcarenite (Lowry 1970) is a thin (up to $7.5 \mathrm{~m}$ thick but usually much less), bioclastic, sandy limestone, which mantles at shallow depth most of the Roe Plains along part of the southern, onshore Eucla Basin in Western Australia, between about Twilight Cove and Eucla (approximate longitudes $126^{\circ}-129^{\circ} \mathrm{E}$ ). The formation is richly fossiliferous, notably of mollusc shells; the milioloid foraminifer Marginopora sp. is conspicuously large and abundant throughout.

The Roe Calcarenite overlies unconformably an erosion surface of, variously, either Wilson Bluff (Eocene) or Abrakurrie (Oligo-Miocene) Limestone (Lowry 1970; Li et al. 1996). The Roe substrate was formed by a fine (toward the base, silty) to medium grained, transgressive, carbonate sand, with extensive seagrass growth, in shallow, inshore, well-circulated water along an open rocky coast. At the time of principal deposition, the shoreline was probably a high sea cliff, now represented by the broadly arcuate Hampton Escarpment, separating the Roe Plains from the more elevated Hampton Tableland and Nullarbor Plain (Lowry 1970).

The study material, from the palaeontological collections of the Western Australian Museum, was collected between 1976 and 1980 from excavations in the Roe Calcarenite, all in proximity to the Hampton Microwave Repeater Tower, a conspicuous landmark (lat. 31 $57^{\prime} 57^{\prime \prime S}$, long. $\left.127^{\circ} 34^{\prime} 45^{\prime \prime} \mathrm{E}\right)$ located $50 \mathrm{~km}$ east of the Madura road house and seven $\mathrm{km}$ south of the Eyre Highway.

\section{Stratigraphy}

The type locality of the present species is a pit, excavated for road fill, and $0.5 \mathrm{~km}$ north from the Hampton Microwave Repeater Tower. There, beneath a thin, brown soil cover, the Roe
Calcarenite measures $2.84 \mathrm{~m}$ in thickness. The uppermost $1.1 \mathrm{~m}$ of the formation presents a strong, top-down, weathering profile.

Here, the base of the Roe Calcarenite overlies unconformably a pitted erosion surface of hard, white limestone, probably the Wilson Bluff Limestone. The basal unit of the Roe is an unlithified, free-running, pale, silty, carbonate sand, $0.55 \mathrm{~m}$ thick and richly fossiliferous, including occasional specimens of the arcoid bivalve Cucullaea $\mathrm{sp}$. This is overlain conformably by a greyish to yellowish, horizontal, shelly calcarenite, $0.15 \mathrm{~m}$ thick and without internal bedding. Passing upward, between 0.7 and $1.1 \mathrm{~m}$ above the base, is a carbonate sand ( $0.4 \mathrm{~m}$ thick), weakly and unevenly lithified and with numerous, large bivalve shells. The holotype of the present species (WAM 81.847) was collected in situ from this unit.

Higher units show the effect of strong, subaerial weathering, with increasing lithification and calcretisation toward the top. The fourth unit (from the base) is a pink, shelly calcarenite, $0.7 \mathrm{~m}$ thick, with extensive, pink, calcrete encrustation of fossil shells and the formation of calcrete nodules. Paratype WAM 81.1774, from an adjacent excavation, appears to have originated from an extension of this unit. The top of the Roe Calcarenite at the type locality is a hard, dense, greyish-brown, shelly, pisolithic calcrete with a laminar surface capping and about $0.4 \mathrm{~m}$ thick.

Age

Early studies of the Mollusca of the Roe Calcarenite (Ludbrook 1958a,b) supported an Early Pleistocene age for the formation and this conclusion was followed by Lowry (1970), Playford et al. (1975) and Ludbrook (1978). However, subsequent collecting enlarged significantly the 
known fauna, enabling a re-evaluation of age in favour of the Late Pliocene (Kendrick et al. 1991: 424). Endorsing this conclusion, Beu and Darragh (2001, figure 6) located the Roe Calcarenite in the Late, though not latest, Pliocene, a view with which the writer fully concurs.

\section{Systematics}

\section{Family Bulimulidae Wenz, 1938}

\section{Genus Bothriembryon Pilsbry, 1894}

Type species: By original designation, Bulimus melo (Quoy and Gaimard) = Helix melo Quoy and Gaimard.

\section{Bothriembryon kremnobates sp. nov. Figure 1A}

\section{Material examined}

\section{Holotype}

WAM 81.847, from Roe Plains, Madura district, Western Australia. Excavation $0.5 \mathrm{~km}$ north of Hampton Microwave Repeater Tower. Taken in situ from carbonate sand with large marine shells, 0.7$1.1 \mathrm{~m}$ above base of Roe Calcarenite. Late Pliocene. Map reference: Yalganimirra 1:100,000 topographical series (1966), 655 630. Collected V.A. Ryland and G.W. Kendrick, 29 September-4 October, 1980. Shell damaged on part of fourth whorl.

\section{Paratypes}

WAM 81.1762, from Roe Plains, Madura district, Western Australia. Excavation $0.5 \mathrm{~km}$ north of Hampton Microwave Repeater Tower. Sieved from spoil heaps on floor of excavation. Roe Calcarenite. Late Pliocene. Collected V.A. Ryland, G.W. and W.E. Kendrick, 20-23 September, 1976. One shell.

WAM 81.1774, from Roe Plains, Madura district, Western Australia. Excavation $1.5 \mathrm{~km}$ north of Hampton Microwave Repeater Tower. From floor of excavation. Collected V.A. Ryland, G.W. and W.E. Kendrick, 22-28 September, 1976. One shell encrusted with pink calcrete.
A
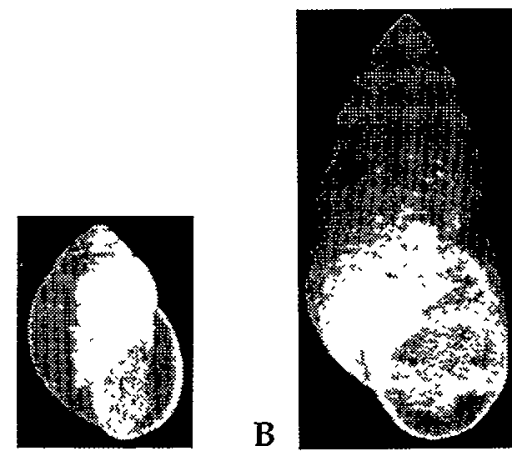

Figure 1 A, Bothriembryon kremnobates sp. nov. Holotype, WAM 81.847. From Roe Plains, Madura district, W.A. Pit $0.5 \mathrm{~km}$ north of Hampton Microwave Repeater Tower: calcarenite with large marine shells, $0.7-1.1 \mathrm{~m}$ above base of Roe Calcarenite. Late Pliocene. Natural size. B, Bothriembryon barretti Iredale. WAM 70.2160d. Large specimen, from excavation, 1-3 $\mathrm{m}$ deep, beside Eyre Highway, $78 \mathrm{~km}$ west of Eucla motel, W.A. Probably from colluvium/soil mantle above Roe Calcarenite. Probably Pleistocene. Natural size.

WAM 81.1796, from Roe Plains, Madura district, Western Australia. Spoil heaps from foundation holes around base of Hampton Microwave Repeater Tower. Collected E. and N. Zeffert, January 1976. One shell.

\section{Diagnosis}

Medium sized, ovate-conical species of Bothriembryon, with about 5.5 whorls in height of 22 $\mathrm{mm}$; higher than wide, maximum diameter exceeding apertural height; spire short, apex blunt, rounded; teleoconch sculpture of weak co-labral growth ridges, lacking subsutural spiral granulation; protoconch with very fine axial wrinkling and punctation.

\section{Description}

Shell of medium size for genus, robust, ovateconical, height exceeding maximum diameter, about 5.5 convex whorls in height of $22 \mathrm{~mm}$; last whorl inflated, spire short, suture impressed; apertural height less than maximum diameter and

Table 1 Dimensions (mm) of Bothriembryon kremnobates sp. nov.

\begin{tabular}{lccccc}
\hline Specimens & $\begin{array}{c}\text { Shell } \\
\text { height }\end{array}$ & $\begin{array}{c}\text { Apertural } \\
\text { height }\end{array}$ & $\begin{array}{c}\text { Max. } \\
\text { diameter }\end{array}$ & $\begin{array}{c}\text { Total } \\
\text { whorls }\end{array}$ & $\begin{array}{c}\text { Protoconch } \\
\text { whorls }\end{array}$ \\
\hline WAM 81.847 holotype & 21.5 & 12.4 & 14.7 & 5.5 & 2.0 \\
WAM 81.1762 paratype & 20.3 & 12.0 & 13.6 & 5.4 & 1.7 \\
WAM 81.1774 paratype & 19.3 & 10.9 & 12.9 & 5.0 & 1.6 \\
WAM 81.1796 paratype & 22 (est.) & 13.0 (est.) & 14.7 (est.) & 5.4 & 2.0 \\
\hline
\end{tabular}

Whorl counts (protoconch and teleoconch) followed the method of Kendrick and Wilson, (1975: 314, figure 1). 
greater than half total shell height; columella short, reflexed across narrow umbilical fissure; teleoconch sculpture of weak, irregular, axial (co-labral) growth ridges, each with a prominent subsutural flexure; no spiral sculpture or subsutural granulation apparent; protoconch of 1.6-2.0 whorls, blunt, tip slightly immersed; microsculpture of very fine, axially aligned wrinkles and punctation.

\section{Etymology}

The name of the species is derived from the Greek kremnobates, a cliff dweller; from the presumed habitat of the species in life.

\section{DISCUSSION}

The presence of a land snail, represented by four separately collected specimens, from a typical marine formation such as the Roe Calcarenite, is noteworthy and invites attention. The formation accumulated along a shallow, near-shore, energised inner shelf in proximity to a cliffed, limestone coastline, now represented by the Hampton Escarpment, a conspicuous land-form of the southern Nullarbor Region (Lowry 1970).
There can be little doubt that the present species lived near or even on the Hampton sea cliff of the Late Pliocene, with the inevitable collapse, from time to time, of rock, soil and associated snail shells into the eroding, transgressive sea below.

Unknown from any other source, the present species is clearly distinct from all known congenors, in particular those now inhabiting the southern Nullarbor Region (Iredale 1939) (Figure 2). Bothriembryon distinctus Iredale differs from the present species in its markedly narrower, more elevated spire (up to seven whorls), its more acute apex and weak subsutural, spiral granulation. Immature (to about five whorls) shells of the large B. dux (Pfeiffer 1861) from the western Nullarbor Region differ strongly in their greater size and in the presence of subsutural spiral granulation. $B$. mastersi (Cox 1867) from western South Australia differs in its smaller, thinner shell, more acute spire with fewer, less inflated whorls, more elevated protoconch with very fine, even micropunctation.

The common, widespread and variable B. barretti Iredale, 1930 more closely resembles the present species than any of the foregoing, especially specimens (of $B$. barretti) from the wider end of its size-range. It differs consistently however in its

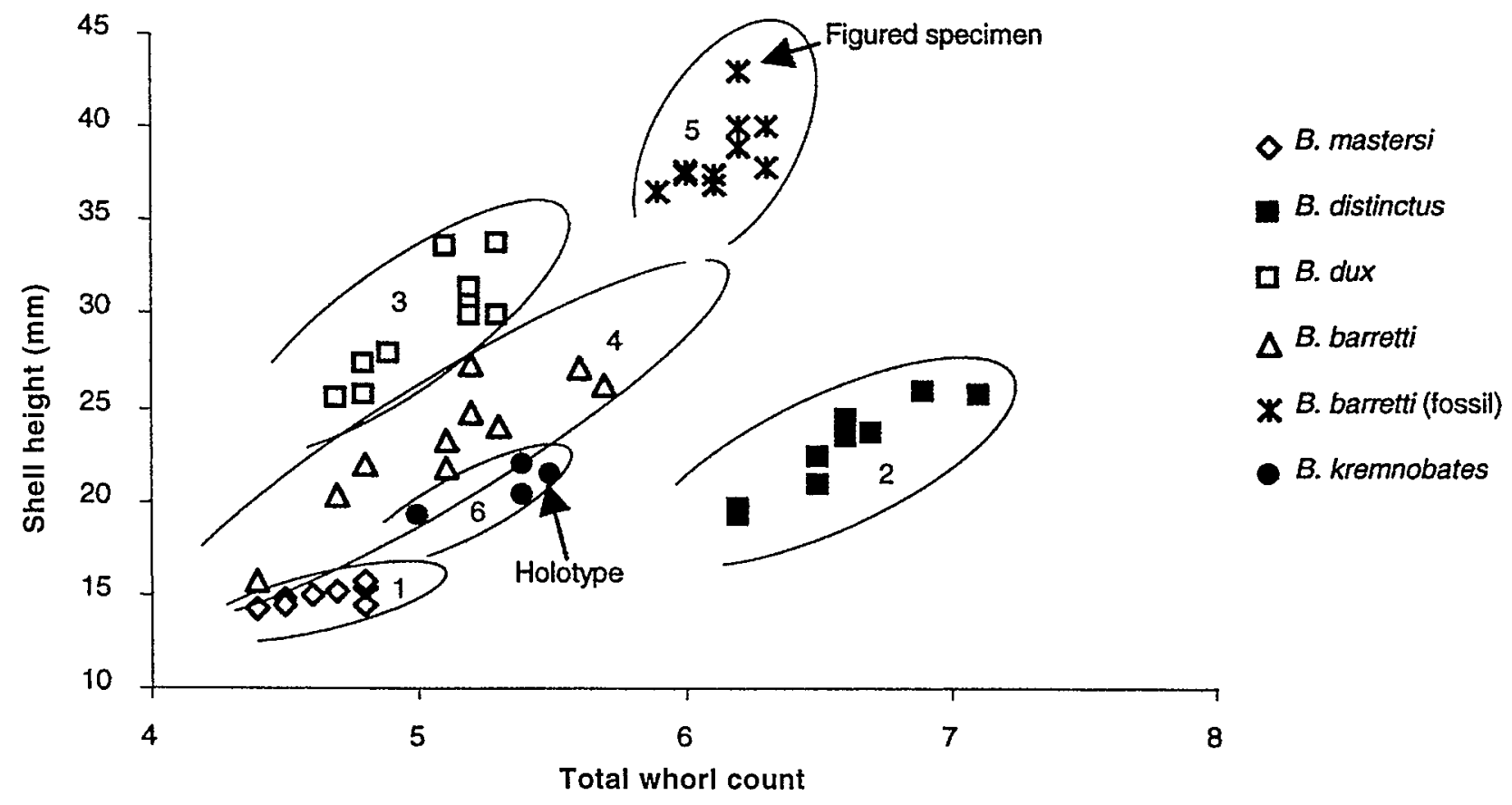

Figure 2 Morphometric comparison (shell height against total whorl count) of Bothriembryon kremnobates sp. nov. with modern and fossil congenors from the southern Nullarbor Region and western South Australia. 1. Bothriembryon mastersi (Cox), WAM S3017, Ceduna, South Australia. Coll. A.R. Main, 21.xii.1952. Modern. 2. B. distinctus Iredale, WAM S2197, $1 \mathrm{~km}$ east of Caiguna, W.A. Coll. S.M. Slack-Smith, 2.i.1977. Modern. 3. B. dux (Pfeiffer), WAM S2526, immature shells from $22.5 \mathrm{~km}$ east of Cocklebiddy, W.A. Coll. W.K. Youngson and A. Baynes, 4.ix.1969. Modern. 4. B. barretti Iredale, WAM S1728, $28 \mathrm{~km}$ west of Madura, W.A. Coll. G.W. Kendrick, 18.ix.1976. Modern. 5. B. barretti Iredale, WAM 70.2160d, large specimens from excavation, 1-3 m deep, beside Eyre Highway, $78 \mathrm{~km}$ west of Eucla motel, W.A. Probably from colluvium/soil mantle above Roe Calcarenite. Probably Pleistocene. 6. B. kremnobates sp. nov., WAM 81.847 (holotype), WAM 81.1762 (paratype), WAM 81.1774 (paratype) and WAM 81.1796 (paratype). For localities, see text. Roe Calcarenite. Late Pliocene. 
more elevated spire and apex and in the welldeveloped, subsutural, spiral granulation. The protoconch of $B$. barretti shows a distinct axial alignment of its microsculpture, not unlike that of the present species.

Ludbrook (1978: 193-194, plate 23, figures 17-19) recorded Bothriembryon barretti barretti Iredale, 1930 and B. barretti indictus Iredale, 1939 from several disturbed surface sites of the Roe Calcarenite, crediting these records to that formation. Specimens of these taxa, often considerably larger (e.g., WAM $70.2160 \mathrm{~d}$, of six whorls in a height of $43 \mathrm{~mm}$ ) than any known modern example of the species, are commonly found on the disturbed surfaces of the many, shallow bulldozer scrapes that characterise the Roe Plains sector of Eyre Highway (Figure 1 B). Such excavations, many of which entered the upper levels of the Roe Calcarenite, were a significant source of the marine fossil material described in Ludbrook's (1978, figure 1, table 2) study of the molluscan assemblage.

The stratigraphic provenance of marine fossils from these disturbed, shallow, roadside sites is beyond challenge but the same cannot be assumed for the associated Bothriembryon specimens, few of which were collected in situ from undisturbed sources (see Kendrick, G.W. in Lowry 1970: 114). Examination of the sedimentary infilling of all $B$. barretti specimens to hand from these disturbed situations (Figure 1B) has shown this infilling invariably to be of non-marine origin and consistent with pedogenic processes located within the colluvium overlying the marine fossil bed. Without knowledge of the precise stratigraphic source of these large $B$. barretti specimens, it would be prudent to view their attribution to the Roe Calcarenite as doubtful and subject to confirmation. A biometric comparison of the above species with B. kremnobates is shown in Figure 2.

By contrast, each of the four known specimens of $B$. kremnobates, comprising the type material, retains, as cavity infilling, sediment typical of the Roe Calcarenite, including small marine fossils. This, and the collection of the holotype from situ, confirms their stratigraphic authenticity and age.

Lowry (1970: 114, fig. 39) reported poorly preserved fossil Bothriembryon, comparable with $B$. barretti, from a palaeosol ("oolitic and pisolitic kankar") overlying Nullarbor Limestone, located 80 miles $(128 \mathrm{~km})$ north of Rawlinna, a locality well beyond the modern geographic range of Iredale's species and possibly significant to regional palaeoclimate.

Fossil records of bulimulid snails in Australia are few. Bothriembryon praecursor McMichael, 1968 was described from Tertiary, possibly Miocene, sediments in the southern Northern Territory (McMichael 1968, Solem 1988) and reported also from dolomitic limestones of the Miocene
Etadunna Formation of northern South Australia (Ludbrook 1980). This species is known only from internal and external moulds and its affinities with other species of the genus and precise age remain to be clarified.

Bulinus gunnii G.B. Sowerby in Strezelecki, 1845 from travertine limestones of uncertain but possible Tertiary age near Hobart, Tasmania, was referred to Bothriembryon by Ludbrook (1980). This species is extremely rare, poorly known and, likewise, its affinities with congenors remain speculative (Solem 1988).

Four fossil species of Bothriembryon from palaeosols in the Pleistocene Tamala Limestone of coastal Western Australia have been described by Kendrick (1978). Two of these, from the Shark Bay district, appear to represent lineages that have become extinct since the Middle Pleistocene.

The present species from the Roe Calcarenite provides the first confirmed record of the genus Bothriembryon from the Pliocene.

\section{ACKNOWLEDGEMENTS}

Contributions in photography and graph preparation by Ms Karen Edward and Mr Corey Whisson are acknowledged with thanks. Access to the collection of modern land snails of the Western Australian Museum was kindly provided by Mrs S.M. Slack-Smith. Mrs A. Nevin prepared the manuscript.

\section{REFERENCES}

Beu, A.G. and Darragh, T.A. (2001). Revision of southern Australian Cenozoic fossil Pectinidae (Mollusca: Bivalvia). Proceedings of the Royal Society of Victoria 113: 1-205.

Iredale, T. (1939). A review of the land Mollusca of Western Australia. Records of the Western Australian Museum and Art Gallery 2: 1-88.

Kendrick, G.W. (1978). New species of fossil nonmarine molluscs from Western Australia and evidence of Late Quaternary climatic change in the Shark Bay district. Journal of the Royal Society of Western Australia 60: 49-60.

Kendrick, G.W. and Wilson, B.R. (1975). Nomenclatural notes on the land snail genus Bothriembryon Pilsbry, 1894 (Pulmonata: Bulimulidae), with redescriptions of the type and two other species. Records of the Western Australian Museum 3: 295-325.

Kendrick, G.W., Wyrwoll, K.-H. and Szabo, B.J. (1991). Pliocene-Pleistocene coastal events and history along the western margin of Australia. Quaternary Science Reviews 10: 419-439.

Li, Q., James, N.P., Bone, Y. and McGowran, B. (1996). Foraminiferal biostratigraphy and depositional environments of the mid-Cenozoic Abrakurrie Limestone, Eucla Basin, southern Australia. Australian Journal of Earth Sciences 43: 437-450. 
Lowry, D.C. (1970). Geology of the Western Australian part of the Eucla Basin. Geological Survey of Western Australia Bulletin 122, $201 \mathrm{p}$.

Ludbrook, N.H. (1958a). The Eucla Basin in South Australia. In M.F. Glaessner and L.W. Parkin (eds) The geology of South Australia, Journal of the Geological Society of Australia 5: 127-135.

Ludbrook, N.H. (1958b). Stratigraphic sequence in the western portion of the Eucla Basin. Journal of the Royal Society of Western Australia 41: 108-114.

Ludbrook, N.H. (1978). Quaternary molluscs of the western part of the Eucla Basin. Geological Survey of Western Australia Bulletin 125, 286 p.

Ludbrook, N.H. (1980). Non-marine molluscs from dolomitic limestones in the north of South Australia. Transactions of the Royal Society of South Australia 104: 83-92.
McMichael, D.F. (1968). Non-marine Mollusca from Tertiary rocks in Northern Australia. Bureau of Mineral Resources, Geology and Geophysics Bulletin 80: 133-157.

Playford, P.E., Cope, R.N., Cockbain, A.E., Low, G.H. and Lowry, D.C. (1975). Phanerozoic. In Geology of Western Australia, Western Australian Geological Survey Memoir 2: 223-433.

Solem, A. (1988). Non-camaenid land snails of the Kimberley and Northern Territory, Australia. 1. Systematics, affinities and ranges. Invertebrate taxonomy 4: 455-604.

Strezelecki, P.E. de, (1845). Physical description of New South Wales and Van Diemens Land, Longman, Brown, Green and Longmans, London. Australiana Facsimile Editions 19. Libraries Board of South Australia, Adelaide.

Manuscript received 30 June 2004; accepted 31 January 2005 